\title{
ANALISIS KONSUMSI PANGAN TINGKAT RUMAH TANGGA DI PROPINSI LAMPUNG
}

\author{
Meliyanah \\ Badan Kepegawaian Daerah Kabupaten Lampung Selatan, Lampung \\ Suhatmini Hardyastuti \& Djuwari \\ Fakultas Pertanian Universitas Gadjah Mada, Yogyakarta
}

\section{ABSTRACT}

This research diamed to: 1) Knowing the selft-price elasticity, cross-price elasticity and income elasticity of consumption per food item on household level according to location and income level; and 2) Knowing the relation between level of income and food consumption on huosehold level according to location and income level.

This research used data from SUSENAS of Lampung Province $n 2002$ with number of sample of 2091 huosehold, which being differed between rural and urban areas based on low, middle, and high level of income. The data analysis used Tobit model and sensiored reggresion.

The result showed that: 1) The demand of rice and beef for household consumption in every level of income in rural and urban areas were inelastic; 2) Corn only been consumed by low income level household in rural areas and the demand was inelastic; 3) The demand of cassava for household consumption on low income level in urban area was elastic, While in middle income level, high income level and every level of income in rural area, cassava demand was inelastic. Cassava was considered as inferior goods; 4) The demand of fish for household consumption an every level of income in rural and urban areas was elastic. Household in rural area on every level of income and in urban areas on middle and high income level consider fish as a main necessity. While on low income level household in urban areas, it was consisdered as classy/exclusive good; 5) The demand of chicken, for household consumption in rural areas on middle and high income level was inelastic. When in rural low income level and urban middle and high income level, was inelastic chicken meat was considend as classy/wxclusive good the rural low income level household; 6) Egg demand for household consumption in rural areas on every level of income was inelastic, while in urban area it was elastic for every level income; 7) The rural and urban household on every level of income considered rice as the stpale food; 8) Household in rural and urban areas on middle and high level of income considered beef as main necessity; and 9) On household with middle income level in rural areas, egg was considered as inferior good; while an low income level in urban areas, egg was considered as expensive good.

Keywords: Food consumption, household, tobit model, elasticity 


\section{PENDAHULUAN}

Pangan dan gizi merupakan kebutuhan yang penting dalam kehidupan manusia untuk mempertahankan hidupnya. Masalah pangan terkait dengan penyediaan, distribusi, harga, konsumsi dan faktor-faktor lainnya. Pangan harus tersedia dalam jumlah yang cukup agar kebutuhan masyarakat dapat terpenuhi dengan baik. Kebutuhan pangan dapat dipenuhi dari dua sumber, yakni produksi dalam negeri dan impor. Pola distribusi pangan yang baik akan mampu menyediakan pangan sesuai dengan jumlah dan kualitas yang dibutuhkan oleh masyarakat. Pangan juga harus tersedia dengan harga yang terjangkau oleh berbagai golongan masyarakat, sehingga kebutuhan pangan minimal untuk hidup layak dapat tercapai.

Ketersediaan pangan yang cukup untuk seluruh penduduk di suatu wilayah belum cukup untuk digunakan sebagai indikator terhindarnya penduduk dari masalah pangan dan gizi. Kebutuhan pangan untuk konsumsi rumah tangga merupakan hal pokok dalam kelangsungan hidup. Untuk itu, selain aspek ketersediannya juga perlu diperhatikan dari aspek pola konsumsi rumah tangga atau keseimbangan kontribusi diantara berbagai jenis pangan yang dikonsumsi, sehingga dapat memenuhi standar gizi yang dianjurkan. Standar gizi yang digunakan yakni: (1) tingkat kecukupan konsumsi kalori per kapita per hari sebesar 2.000 kalori; dan (2) tingkat kecukupan konsumsi protein sebesar 45 gram per kapita per hari (BPS, 2002).

Pola konsumsi rumah tangga berdasarkan data Hasil Survei Sosial Ekonomi Nasional (SUSENAS) pada tahun 1996, 1999 dan 2002 menunjukkan bahwa sebagian besar pengeluaran rumah tangga dialokasikan pada konsumsi pangan. Pengeluaran rumah tangga untuk konsumsi pangan di Propinsi Lampung dapat dilihat pada tabel 1.

Tabel 1. Rata-rata Pengeluaran per Kapita sebulan (dalam rupiah) untuk Kelompok Pangan di Propinsi Lampung Tahun 1996, 1999 dan 2002

\begin{tabular}{lcccccc}
\hline \multirow{2}{*}{ Kelompok Barang } & \multicolumn{3}{c}{ Perkotaan } & \multicolumn{3}{c}{ Pedesaan } \\
\cline { 2 - 6 } & 1996 & 1999 & 2002 & 1996 & 1999 & 2002 \\
\hline Padi-padian & 7.972 & 21.285 & 23.788 & 8.714 & 23.967 & 26.961 \\
Umbi-umbian & 409 & 716 & 1.143 & 578 & 1.573 & 1.701 \\
Ikan & 3.121 & 7.410 & 9.385 & 2.073 & 4.732 & 6.589 \\
Daging & 2.250 & 4.070 & 6.505 & 1.359 & 1.755 & 2.092 \\
Telur dan Susu & 2.533 & 6.306 & 8.024 & 1.409 & 2.678 & 3.815 \\
Sayur-sayuran & 3.854 & 11.482 & 10.097 & 3.909 & 9.776 & 10.082 \\
Kacang-kacangan & 1.476 & 4.687 & 4.719 & 1.322 & 3.098 & 3.827 \\
Buah-buahan & 1.860 & 3.939 & 5.652 & 1.343 & 2.031 & 2.981 \\
Minyak dan Lemak & 1.620 & 4.707 & 4.315 & 1.793 & 4.207 & 4.603 \\
Bahan Minuman & 2.247 & 5.130 & 6.423 & 2.058 & 4.531 & 5.863 \\
Bumbu-Bumbuan & 841 & 2.376 & 2.827 & 853 & 2.152 & 2.903 \\
Kosumsi lainnya & 1.171 & 2.774 & 2.962 & 491 & 1.031 & 1.628 \\
Makanan jadi & 5.342 & 15.329 & 18.518 & 2.188 & 4.731 & 5.645 \\
Minuman mengandung & 31 & 64 & 109 & 25 & 32 & 67 \\
alkohol & & & & & & \\
Tembakau, sirih & 4.224 & $\mathbf{9 . 1 7 5}$ & 15.403 & 2.733 & 6.407 & 11.120 \\
\hline Total & $\mathbf{3 8 . 9 5 2}$ & $\mathbf{9 9 . 4 5 1}$ & $\mathbf{1 1 9 . 8 6 9}$ & $\mathbf{3 0 . 8 4 6}$ & $\mathbf{7 2 . 7 0 1}$ & $\mathbf{8 9 . 8 7 7}$ \\
\hline
\end{tabular}


Tabel 1 menunjukkan bahwa kelompok barang padi-padian pada tahun 1996, 1999 dan 2002 merupakan kelompok barang terbesar yang dibelanjakan oleh masyarakat Propinsi Lampung, baik diperkotaan maupun pedesaan. Namun jika dilihat dari persentasenya terhadap total pengeluaran pangan rumah tangga, pada tahun 2002 mengalami penurunan jika dibandingkan dengan tahun 1996 dan 1999. Pada daerah perkotaan tahun 1996 dan 1999, masing-masing sebesar 20,35 persen dan 21,40 perșen sedangkan pada tahun 2002 sebesar 19,84 persen. Pada daerah pedesaan tahun 1999 sebesar 32,97 persen sedangkan pada tahun 2002 sebesar 30,00 persen.

Pola dan tingkat konsumsi terhadap suatu pangan sangat dipengaruhi oleh tingkat harga pangan yang bersangkutan, harga pangan lain yang memiliki hubungan dengan pangan tersebut, tingkat pendapatan dan selera. Dalam analisis jangka pendek dapat diasumsikan tidak terdapat perubahan selera, oleh karena itu, konsumsi pangan ditentukan tingkat harga-harga dan pendapatan.

Berg (1986) menyatakan bahwa pendapatan, harga-harga dan selera merupakan faktor yang menentukan kuantitas dan kualitas barang yang dikonsumsi. Selain itu tingkat konsumsi pangan juga dipengaruhi oleh letak geografis (desa dan kota) dan budaya setempat.

Studi tentang analisis konsumsi pangan pada tingkat rumah tangga telah dilakukan oleh beberapa peneliti, diantaranya Onianti (2002), meneliti konsumsi buahbuahan pada tingkat rumah tangga di daerah Istimewa Yogyakarta, dengan menggunakan data SUSENAS tahun 1999 dan Mulatsih (2003), meneliti tentang distribusi pengeluaran konsumsi per kapita di Indonesia dan faktor-faktor yang mempengaruhinya 1987-1999.

Penelitian ini bertujuan untuk mengetahui: (a) elastisitas harga sendiri, elastisitas harga silang dan elastisitas pendapatan dari konsumsi per jenis pangan pada tingkat rumah tangga menurut lokasi dan tingkat pendapatan; dan (b) hubungan antara tingkat pendapatan dan konsumsi pangan pada tingkat rumah tangga menurut lokasi dan tingkat pendapatan.

\section{METODE PENELITIAN}

Penelitian dilaksanakan di Propinsi Lampung yang dilakukan dengan cakupan seluruh kabupaten/kota. Penentuan sampel dalam penelitian ini menggunakan metode yang digunakan oleh Badan Pusat Statistik (BPS) dalam SUSENAS 2002. Dalam penelitian ini menggunakan sampel sebesar 2091 yang dicacah Kor+Modul. Jenis data yang digunakan dalam penelitian ini adalah data sekunder, yaitu data penampang lintang (cross section), SUSENAS tahun 2002 di Propinsi Lampung yang dikumpulkan oleh BPS. Data yang digunakan adalah data pengeluaran dan konsumsi pangan rumha tangga serta karakteristik sosiodemografi rumah tangga sampel (pendidikan dan jumlah anggota rumah tangga).

Salah satu metode estimasi konsumsi pangan tingkat rumah tangga yang banyak digunakan adalah metode tobit atau model regresi tersensor. Metode ini telah banyak digunakan seperti oleh Greene (1993), Endang (1998), maupun Wijayanti (1999). Pendekatan model tobit juga pernah digunakan misalnya oleh Nguyen (1999), De Rosari (2000), Onianti (2002) maupun Mulatsih (2003).

Model analisis mencakup analisis setiap jenis pangan yang dikonsumsi oleh rumah tangga pada tingkat pendapatan rendah, menengah dan tinggi di daerah perkotaan 
dan pedesaan. Model analisis dalam penelitian ini dapat dituliskan dalam persamaan berikut ini:

$$
\begin{aligned}
Y_{1-7}= & \hat{\beta}_{0}+\hat{\beta}_{1} X_{1}+\hat{\beta}_{2} X_{2}+\hat{\beta}_{3} X_{3}+\hat{\beta}_{4} X_{4}+\hat{\beta}_{5} X_{5}+\hat{\beta}_{6} X_{6}+\hat{\beta}_{7} X_{7}+ \\
& \hat{\beta}_{8} X_{8}+\hat{\beta}_{9} X_{9}+\hat{\beta}_{10} X_{10}+\varepsilon_{i}
\end{aligned}
$$

keterangan :

$\mathrm{Y}_{1}=$ Konsumsi beras tiap rumah tangga setiap bulan ( $\left.\mathrm{kg} / \mathrm{bulan}\right)$

$\mathrm{Y}_{2}=$ Konsumsi jagung tiap rumah tangga setiap bulan $(\mathrm{kg} / \mathrm{bulan})$

$\mathrm{Y}_{3}=$ Konsumsi ubi kayu tipa rumah tangga setiap bulan ( $\mathrm{kg} /$ bulan)

$\mathrm{Y}_{4}=$ Konsumsi ikan tiap rumah tangga setiap bulan $(\mathrm{kg} / \mathrm{bulan})$

$\mathrm{Y}_{5} \quad=$ Konsumsi daging sapi tiap rumah tangga setiap bulan (kg/bulan)

$\mathrm{Y}_{6}=$ Konsumsi daging ayam tiap rumah tangga setiap bulan $(\mathrm{kg} / \mathrm{bulan})$

$\mathrm{Y}_{7}=$ Konsumsi telur tiap rumah tangga setiap bulan $(\mathrm{kg} / \mathrm{bulan})$

$\mathrm{X}_{1}=$ Harga beras $(\mathrm{Rp} / \mathrm{kg})$

$\mathrm{X}_{2} \quad=$ Harga jagung $(\mathrm{Rp} / \mathrm{kg})$

$\mathrm{X}_{3}=$ Harga ubi kayu $(\mathrm{Rp} / \mathrm{kg})$

$\mathrm{X}_{4} \quad=$ Harga ikan $(\mathrm{Rp} / \mathrm{kg})$

$\mathrm{X}_{5} \quad=$ Harga daging sapi $(\mathrm{Rp} / \mathrm{kg})$

$\mathrm{X}_{6} \quad=$ Harga daging ayam $(\mathrm{Rp} / \mathrm{kg})$

$\mathrm{X}_{7}=$ Harga telur $(\mathrm{Rp} / \mathrm{kg})$

$\mathrm{X}_{8}=$ Pendapatan rumah tangga $(\mathrm{Rp} / \mathrm{kg})$

$\mathrm{X}_{9}=$ Pendidikan kepala rumah tangga (tahun)

$\mathrm{X}_{10}$ = Jumlah anggota rumah tangga (orang)

$\hat{\beta}_{0}=$ Intercept

$\hat{\beta}_{1}-\hat{\beta}_{10}=$ Koefisien regresi

$\varepsilon_{i}=$ Error

Persamaan untuk menghitung nilai elastisitas diuraikan sebagai berikut:

(a) Untuk menghitung nilai elastisitas harga sendiri dari masing-masing jenis pangan yang dikonsumsi, digunakan rumus:

$$
\operatorname{cop}_{\mathrm{i}}=\beta \operatorname{op}_{i} x\left[\frac{K_{i}}{K_{i}+T K_{i}}\right] x \frac{O \bar{P}_{i}}{\bar{C}_{i}}
$$

(b) Untuk menghitung nilai elastisitas harga silang dari masing-masing jenis pangan yang dikonsumsi, digunakan rumus :

$$
\epsilon \mathrm{cp}_{\mathrm{j}}=\beta c p_{j} x\left[\frac{K_{i}}{K_{i}+T K_{i}}\right] x \frac{O \bar{P}_{j}}{\bar{C}_{i}}
$$

(c) Untuk menghitung nilai elastisitas pendapatan dari masing-masing jenis pangan yang dikonsumsi, digunakan rumus : 


$$
\eta_{\mathrm{i}}=\beta x\left[\frac{K_{i}}{K_{i}+T K_{i}}\right] x \frac{\bar{I}}{\bar{C}_{i}}
$$

\section{Keterangan :}

åop $_{\mathrm{i}}=$ elastisitas harga sendiri dari konsumsi pangan ke-i

åcp = elastisitas harga silang dari konsumsi pangan ke-j

$c_{\mathrm{i}} \quad$ = elastisitas pendapatan terhadap konsumsi pangan ke-i

$\mathrm{K}_{\mathrm{i}} \quad$ = jumlah sampel rumah tangga yang mengkonsumsi pangan ke-i

$\mathrm{TK}_{\mathrm{i}}=$ jumlah sampel rumah tangga yang tidak mengkonsumsi pangan ke-i

$\mathrm{Ki} /\left(\mathrm{K}_{\mathrm{i}}+\mathrm{TK}_{\mathrm{i}}\right)=$ proporsi rumah tangga yang mengkonsumsi pangan ke-i

âop $_{\mathrm{i}}=$ koefisien regresi harga sendiri dari konsumsi pangan ke-i

$\hat{a ̂ o p}_{\mathrm{j}}=$ koefisien regresi harga silang dari konsumsi pangan ke-j

$\hat{\mathrm{a}}_{\mathrm{i}} \quad=$ koefisien regresi pendapatan terhadap konsumsi pangan ke-i

$O \bar{P}_{i}=$ rata-rata harga pangan itu sendiri atau pangan ke-i

$C \bar{P}_{j=\text { rata-rata harga pangan lain atau pangan ke-j }}$

$\bar{C}_{i}=$ rata-rata konsumsi pangan ke-i

$\bar{I}=$ rata-rata pendapatan rumah tangga

$$
\beta x\left[\frac{K_{i}}{K_{i}+T K_{i}}\right]=\text { efek marginal }
$$

\section{HASIL PEMBAHASAN}

\section{Elastisitas Konsumsi Pangan Rumah Tangga}

Pada penelitian ini, elastisitas konsumsi dibedakan menjadi 3 (tiga) jenis, yakni elastisitas yang dikaitkan dengan harga barang disebut elastisitas harga sendiri (owner price elasticity of demand). Sedangkan elastisitas yang dikaitkan dengan harga barang lain disebut elastisitas silang (cross elastisity) dan bila dikaitkan dengan pendapatan disebut elastisitas pendapatan (income elasticity).

\section{Elastisitas Konsumsi Beras}

Hasil analisis elastisitas harga sendiri, elastisitas harga silang dan elastisitas pendapatan konsumsi beras rumah tangga di pedesaan dan perkotaan pada berbagai tingkat pendapatan dapat dilihat pada tabel 2 dan tabel 3. 
Tabel 2. Elastisitas Harga Sendiri, Harga Silang dan Pendapatan Terhadap Konsumsi Beras Rumah Tangga Pada Daerah Pedesaan Menurut Tingkat Pendapatan di Propinsi Lampung.

\begin{tabular}{lrrr}
\hline \multirow{2}{*}{ Elastisitas } & \multicolumn{3}{c}{ Tingkat Pendapatan } \\
\cline { 2 - 4 } & \multicolumn{1}{c}{ Rendah } & Menengah & \multicolumn{1}{c}{ Tinggi } \\
\hline Elastisitas Harga Beras & $-0,188^{*}$ & $-0,088^{*}$ & $-0,029$ \\
Elastisitas Harga Silang : & & & $(-)$ \\
Harga Jagung & 0,001 & 0,000001 & $-0,000154$ \\
Harga Ubi Kayu & $-0,000019$ & $-0,001^{*}$ & $-0,002$ \\
Harga Ikan & $-0,002^{*}$ & $-0,013$ & 0,001 \\
Harga Daging Sapi & $(-)$ & $-0,001$ & 0,002 \\
Harga Daging Ayam & $-0,008$ & $-0,001^{*}$ & 0,001 \\
Harga Telur & $-0,001$ & $0,046^{*}$ & $0,072^{*}$ \\
Elastisitas Pendapatan & $0,166^{*}$ & &
\end{tabular}

Sumber : Analisis Data Susenas, 2002.

Keterangan : * Signifikan pada taraf kesalahan 5\%

( - ) Rumah tangga tidak mengkonsumsi pangan tersebut

Tabel 3. Elastisitas Harga Sendiri, Harga Silang dan Pendapatan Terhadap Konsumsi Beras Rumah Tangga Pada Daerah Perkotaan Menurut Tingkat Pendapatan di Propinsi Lampung

\begin{tabular}{lrrr}
\hline \multirow{2}{*}{ Elastisitas } & \multicolumn{3}{c}{ Tingkat Pendapatan } \\
\cline { 2 - 4 } & \multicolumn{1}{c}{ Rendah } & Menengah & \multicolumn{1}{c}{ Tinggi } \\
\hline Elastisitas Harga Beras & $-0,573$ & $-0,172^{*}$ & $-0,645^{*}$ \\
Elastisitas Harga Silang : & & & \\
Harga Jagung & $(-)$ & $(-)$ & $(-)$ \\
Harga Ubi Kayu & $-0,000006$ & $0,0004^{*}$ & $-0,00003$ \\
Harga Ikan & $-0,004$ & $-0,003^{*}$ & $-0,001$ \\
Harga Daging Sapi & $(-)$ & $-0,0002$ & $-0,009$ \\
Harga Daging Ayam & $(-)$ & $-0,003$ & 0,002 \\
Harga Telur & 0,001 & $-0,002$ & 0,001 \\
Elastisitas Pendapatan & 0,198 & $0,112^{*}$ & 0,084 \\
\hline
\end{tabular}

Sumber : Analisis Data Susenas, 2002.

Keterangan: * Signifikan pada taraf kesalahan 5\%

( - ) Rumah tangga tidak mengkonsumsi pangan tersebut

Secara umum untuk rumah tangga pedesaan maupun perkotaan pada berbagai tingkat pendapatan, nilai elastisitas harga beras mempunyai nilai negatif, hal ini sesuai dengan hukum permintaan, yang menyatakan bahwa "bila harga suatu barang naik maka ceteris paribus jumlah yang diminta konsumen akan barang tersebut turun dan sebaliknya bila harga barang tersebut turun". Sedangkan nilai elastisitas harga beras, menunjukkan nilai yang lebih kecil dari satu artinya permintaan beras untuk konsumsi rumah tangga bersifat inelastis artinya persentase perubahan beras yang diminta lebih kecil dari persentase perubahan harga beras. 
Nilai elastisitas harga barang lain terhadap konsumsi beras untuk rumah tangga pedesaan maupun perkotaan pada berbagai tingkat pendapatan, pada umumnya beras mempunyai hubungan komplementer dengan ikan karena pada umumnya rumah tangga mengkonsumsi ikan sebagai pelengkap nasi. Pada tingkat pendapatan menengah di perkotaan, beras mempunyai hubungan substitusi dengan ubi kayu sedangkan pada tingkat pendapatan tinggi di pedesaan beras dan ubi kayu mempunyai hubungan bersifat komplementer. Diduga hal ini disebabkan oleh perbedaan tingkat pendapatan, sehingga rumah tangga pendapatan tinggi dapat mengkonsumsi beras dan ubi kayu secara bersama-sama sedangkan tingkat pendapatan menengah tidak dapat mengkonsumsi beras dan ubi kayu bersama-sama, melainkan saling menggantikan karena keterbatasan tingkat pendapatan.

Nilai elastisitas pendapatan baik di pedesaan maupun diperkotaan pada berbagai tingkat pendapatan menunjukkan bahwa beras merupakan barang kebutuhan pokok, hal ini disebabkan karena kenaikan pendapatan menyebabkan rumah tangga meningkatkan konsumsi beras namun dengan proporsi yang lebih kecil dari kenaikan pendapatan tersebut.

\section{Elastisitas Konsumsi Jagung}

Hasil analisis elastisitas harga sendiri, elastisitas harga silang dan elastisitas pendapatan konsumsi jagung rumah tangga di pedesaan pada tingkat pendapatan rendah selengkapnya dapat dilihat pada tabel 4.

Tabel 4 menunjukkan bahwa pada tingkat pendapatan rendah di pedesaan, nilai elastisitas harga jagung sebesar -0,035 artinya permintaan jagung untuk konsumsi rumah tangga bersifat inelastis, yaitu jika harga jagung meningkat $1 \%$ maka konsumsi jagung akan turun sebesar $0,035 \%$ dengan proporsi lebih kecil dari proporsi kenaikan harga jagung dan sebaliknya jika harga jagung turun maka konsumsi jagung akan meningkat dengan proporsi yang lebih kecil dari proporsi kenaikan jagung. Sedangkan nilai elastisitas harga silang dan elastisitas pendapatan tidak signifikan secara statistik.

Tabel 4. Elastisitas Harga Sendiri, Harga Silang dan Pendapatan Terhadap Konsumsi Jagung Rumah Tangga Daerah Pedesaan pada tingkat Pendapatan Rendah di Propinsi Lampung

\begin{tabular}{lr}
\hline \multicolumn{1}{c}{ Elastisitas } & Nilai Elastisitas \\
\hline Elastisitas Harga Jagung & $-0,035^{*}$ \\
Elastisitas Harga Silang: & \\
Harga Beras & 0,00003 \\
Harga Ubi Kayu & 0,000018 \\
Harga Ikan & $-0,001$ \\
Harga Daging Sapi & $(-)$ \\
Harga Daging Ayam & 0,002 \\
Harga Telur & 0,00005 \\
Elastisitas Pendapatan & $-0,060$ \\
\hline Sumber : Analisis Data Susenas, 2002.
\end{tabular}

Keterangan: * Signifikan pada taraf kesalahan 5\%

( - ) Rumah tangga tidak mengkonsumsi pangan tersebut 


\section{Elastisitas Konsumsi Ubi Kayu}

Hasil analisis elastisitas harga sendiri, elastisitas harga silang dan elastisitas pendapatan konsumsi ubi kayu rumah tangga di pedesaan dan perkotaan pada berbagai tingkat pendapatan selengkapnya dapat dilihat pada tabel 5 dan 6.

Tabel 5. Elastisitas Harga Sendiri, Harga Silang dan Pendapatan Terhadap Konsumsi Ubi Kayu Rumah Tangga pada Daerah Pedesaan Menurut Tingkăt Pendapatan di Propinsi Lampung.

\begin{tabular}{lrrr}
\hline \multirow{2}{*}{ Elastisitas } & \multicolumn{3}{c}{ Tingkat Pendapatan } \\
\cline { 2 - 4 } & \multicolumn{1}{c}{ Rendah } & Menengah & \multicolumn{1}{c}{ Tinggi } \\
\hline Elastisitas Harga Ubi & $-0,242^{*}$ & $-0,234^{*}$ & $-0,217^{*}$ \\
Kayu & & & \\
Elastisitas Harga Silang: & & & \\
$\quad$ Harga Beras & 0,002 & 0,017 & $-0,174$ \\
$\quad$ Harga Jagung & 0,002130 & $(-)$ & $(-)$ \\
$\quad$ Harga Ikan & $-0,004^{*}$ & $-0,004^{*}$ & $-0,002$ \\
Harga Daging Sapi & $(-)$ & 0,021 & 0,004 \\
$\quad$ Harga Daging Ayam & 0,011 & 0,005 & 0,006 \\
$\quad$ Harga Telur & $-0,012$ & $-0,001$ & $-0,003$ \\
Elastisitas Pendapatan & 0,056 & $-0,197^{*}$ & $-0,118$ \\
\hline
\end{tabular}

Sumber : Analisis Data Susenas, 2002.

Keterangan : * Signifikan pada taraf kesalahan 5\%

( - ) Rumah tangga tidak mengkonsumsi pangan tersebut

Tabel 6. Elastisitas Harga Sendiri, Harga Silang dan Pendapatan Terhadap Konsumsi Ubi Kayu Rumah Tangga Pada Daerah Perkotaan Menurut Tingkat Pendapatan di Propinsi Lampung.

\begin{tabular}{lrrr}
\hline \multirow{2}{*}{ Elastisitas } & \multicolumn{3}{c}{ Tingkat Pendapatan } \\
\cline { 2 - 4 } & \multicolumn{1}{c}{ Rendah } & Menengah & \multicolumn{1}{c}{ Tinggi } \\
\hline Elastisitas Harga Ubi Kayu & $-2,887^{*}$ & $-0,619^{*}$ & $-0,487^{*}$ \\
Elastisitas Harga Silang : & & & \\
Harga Beras & $3,452^{*}$ & $-0,129$ & $-0,002$ \\
Harga Jagung & $(-)$ & $(-)$ & $(-)$ \\
Harga Ikan & $-0,064^{*}$ & $-0,01$ & $-0,011$ \\
Harga Daging Sapi & $(-)$ & $-0,001$ & $-0,020$ \\
Harga Daging Ayam & $(-)$ & 0,005 & 0,007 \\
Harga Telur & $-0,078^{*}$ & $-0,01^{*}$ & $-0,003$ \\
Elastisitas Pendapatan & $-5,939^{*}$ & $-0,321$ & $-0,03$ \\
\hline
\end{tabular}

Sumber : Analisis Data Susenas, 2002.

Keterangan : * Signifikan pada taraf kesalahan 5\%

( - ) Rumah tangga tidak mengkonsumsi pangan tersebut

Secara umum untuk rumah tangga pedesaan maupun perkotaan pada berbagai tingkat pendapata, nilai elastisitas harga ubi kayu mempunyai nilai negatif, hal ini sesuai dengan hukum permintaan, yang menyatakan bahwa " nilai harga suatu barang naik maka ceteris paribus jumlah yang diminta konsumen akan barang tersebut turun dan 
sebaliknya bila harga barang tersebut turun”. Nilai elastisitas harga ubi kayu yang lebih kecil dari satu artinya permintaan ubi kayu untuk konsumsi rumah tangga bersifat inelastis artinya persentase perubahan ubi kayu yang diminta lebih kecil dari persentase perubahan harga ubi kayu. Sedangkan nilai elastisitas harga ubi kayu yang lebih besar satu artinya permintaan ubi kayu untuk konsumsi rumah tangga bersifat elastis artinya persentase perubahan ubi kayu yang diminta lebih besar dari persentase perubahan
harga ubi kayu.

Nilai elastisitas harga barang lain terhadap konsumsi beras untuk rumah tangga pedesaan maupun perkotaan pada berbagai tingkat pendapatan, pada umumnya ubi kayu mempunyai hubungan komplementer dengan ikan, dan telur karena pada umumnya rumah tangga mengkonsumsi ikan sebagai pelengkap ubi kayu. Pada tingkat pendapatan menengah dan tinggi di pedesaan, ubi kayu mempunyai hubungan substitusi dengan mempunyai hubungan yang bersifat substitusi di perkotaan ubi kayu dan beras tinggi di pedesaan beras dan ubi kayu mempusi, sedangkan pada tingkat pendapatan Diduga hal ini disebabkan oleh perbedaan tingkat pendapungan yang bersifat substitusi. pendapatan tinggi di pedesaan dapat mengkendapatan, sehingga rumah tangga sama sedangkan tingkat pendapatan rendan sumsi beras dan ubi kayu secara bersamaberas dan ubi kayu secara bersama-ndah di perkotaan tidak dapat mengkonsumsi keterbatasan tingkat pendapatan.

Nilai elastisitas pendapatan baik di pedesaan maupun diperkotaan pada berbagai tingkat menunjukkan bahwa ubi kayu merupakan barang inferior, ini berarti apabila pendapatan meningkat maka konsumsi ubi kayu berkurang atau sebaliknya ubi kayu yang dikonsumsi akan meningkat dengan berkurangnya pendapatan.

\section{Elastisitas Konsumsi Ikan}

Hasil analisis harga sendiri, elastisitas harga silang dan elastisitas pendapatan konsumsi ikan rumah tangga di pedesaan dan perkotaan pada berbagai tingkat
pendapatan selengkapnya dilihat pada tabel 7 dan 8 .

Tabe1 7. Elastisitas Harga Sendiri, Harga Silang dan Pendapatan Terhadap Konsumsi Ikan Rumah Tangga Pada Daerah Pedesaan Menurut Tingkat Pendapatan di Propinsi Lampung

\begin{tabular}{lrrr} 
Elastisitas & \multicolumn{3}{c}{ Tingkat Pendapatan } \\
\cline { 2 - 4 } Elastisitas Harga Ikan & Rendah & Menengah & \multicolumn{1}{c}{ Tinggi } \\
Elastisitas Harga Silang : & $-1,642^{*}$ & $-1,616^{*}$ & $-1,313^{*}$ \\
Harga Beras & & & \\
Harga Jagung & $-0,008$ & $-0,114$ & $-0,252$ \\
Harga Ubi Kayu & $-0,0038$ & $(-)$ & $(-)$ \\
Harga Daging Sapi & $-0,00002$ & $-0,001^{*}$ & $-0,0002$ \\
Harga Daging Ayam & $(-)$ & 0,049 & $0,091^{*}$ \\
Harga Telur & 0,021 & 0,009 & 0,004 \\
Elastisitas Pendapatan & $-0,003$ & $-0,004$ & $0,012^{*}$ \\
Sumber: Analisis Data Susenas, 2002. & 0,203 & 0,038 & 0,064 \\
Keterangan : * Signifikan pada taraf kesalahan 5\% & \\
\multicolumn{4}{c}{ ( - ) Rumah tangga tidak mengkonsumsi pangan tersebut } \\
44
\end{tabular}


Tabel 8. Elastisitas Harga Sendiri, Harga Silang dan Pendapatan Terhadap Konsumsi Ikan Rumah Tangga Pada Daerah Perkotaan Menurut tingkat Pendapatan di Propinsi Lampung

\begin{tabular}{lrrr}
\hline \multirow{2}{*}{ Elastisitas } & \multicolumn{3}{c}{ Tingkat Pendapatan } \\
\cline { 2 - 4 } & \multicolumn{1}{c}{ Rendah } & Menengah & \multicolumn{1}{c}{ Tinggi } \\
\hline Elastisitas Harga Ikan & $-5,644^{*}$ & $-2,737^{*}$ & $-2,322^{*}$ \\
Elastisitas Harga Silang : & & & \\
Harga Beras & $-1,269$ & $-0,367$ & $-0,005$ \\
Harga Jagung & $(-)$ & $(-)$ & $(-)$ \\
Harga Ubi Kayu & $-0,006^{*}$ & $-0,001$ & $-0,031^{*}$ \\
Harga Daging Sapi & $(-)$ & 0,002 & $-0,076^{*}$ \\
Harga Daging Ayam & $(-)$ & $-0,002$ & 0,020 \\
Harga Telur & 0,039 & $-0,004$ & 0,011 \\
Elastisitas Pendapatan & 1,151 & $0,905^{*}$ & 0,050 \\
\hline
\end{tabular}

Sumber : Analisis Data Susenas, 2002.

Keterangan : * Signifikan pada taraf kesalahan 5\%

( - ) Rumah tangga tidak mengkonsumsi pangan tersebut

Secara umum untuk rumah tangga pedesaan maupun perkotaan pada berbagai tingkat pendaptan, nilai elastisitas harga ikan mempunyai nilai negatif, hal ini sesuai dengan hukum permintaan, yang menyatakan bahwa "bila harga suatu barang naik maka centeris paribus jumlah yang diminta konsumen kan barang tersebut turun dan sebailknya bila harga harga barang turun". Nilai elastisitas harga ikan yag lebih besar dari satu artinya permintaan ikan untuk konsumsi rumah tangga bersifat elastis artinya persentase perubahan ikan yang diminta lebih besar dari persentase perubahan harga ikan.

Nilai elastisitas harga barang lain terhadap konsumsi ikan untuk rumah tangga di pedesaan maupun perkotaan pada berbagai tingkat pendapatan, pada umumnya ikan mempunyai hubungan komplementer dengan ubi kayu karena pada umumnya rumah tangga mengkonsumsi ikan sebagai pelengkap ubi kayu. Pada tingkat pendapatan menengah di pedesaan, ikan mempunyai hubungan komplementer dengan telur, namun pada tingkat pendapatan tinggi di pedesaan ikan mempunyai hubungan substitusi dengan telur dan daging sapi. Pada tingkat pendapatan tinggi di perkotaan ikan mempunyai hubungan yang bersifat substitusi dengan daging ayam. Nilai elastisitas pendapatan baik di pedesaan maupun diperkotaan pada berbagai tingkat pendapatan baik di pedesaan maupun perkotaan pada berbagai tingkat pendapatan menunjukkan bahwa ikan merupakan barang kebutuhan pokok, ini berarti apabila pendapatan meningkat maka konsumsi ikan bertambah atau sebaliknya namun proporsi peningkatan konsumsi ikan lebih kecil daripada proporsi kenaikan pendapatan.

\section{Elastisitas Konsumsi Daging Sapi}

Hasil analisis elastisitas harga sendiri, elastisitas harga silang dan elastisitas pendapatan konsumsi daging sapi rumah tangga di pedesaan dan perkotaan pada berbagai tingkat pendapatan dapat dilihat pada tabel 9 dan 10 . 
Tabel 9. Elastisitas Harga Sendiri, Harga Silang dan Pendapatan Terhadap Konsumsi Daging Sapi Rumah Tangga pada Daerah Pedesaan Menurut Tingkat Pendapatan di Propinsi Lampung

\begin{tabular}{lrr}
\hline \multirow{2}{*}{ Elastisitas } & \multicolumn{2}{c}{ Tingkat Pendapatan } \\
\cline { 2 - 3 } & \multicolumn{2}{c}{ Menengah } \\
\hline Elastisitas Harga Daging Sapi & $-0,137^{*}$ & $-0,049^{*}$ \\
Elastisitas Harga Silang : & & \\
Harga Beras & $-0,002$ & $-0,097$ \\
Harga Jagung & $(-)$ & $(-)$ \\
Harga Ubi Kayu & $-0,0002$ & $-0,0003$ \\
Harga Ikan & 0,0001 & 0,027 \\
Harga Daging Ayam & 0,002 & 0,003 \\
Harga Telur & $-0,001^{*}$ & 0,00005 \\
Elastisitas Pendapatan & $0,147^{*}$ & 0,016 \\
\hline Sumber : Analisis Data Susenas, 2002 & &
\end{tabular}

Keterangan : $\quad *$ Signifikan pada taraf kesalahan 5\%

( - ) Rumah tangga tidak mengkonsumsi pangan tersebut

Tabel 10. Elastisitas Harga Sendiri, Harga Silang dan Pendapatan Terhadap Konsumsi Daging Sapi Rumah Tangga pada Daerah Perkotaan Menurut Tingkat Pendapatan di Propinsi Lampung

\begin{tabular}{|c|c|c|}
\hline \multirow{2}{*}{ Elastisitas } & \multicolumn{2}{|c|}{ Tingkat Pendapatan } \\
\hline & Menengah & Tinggi \\
\hline Elastisitas Harga Daging Sapi & $-0,002^{*}$ & $-0,279 *$ \\
\hline Elastisitas Harga Silang: & & \\
\hline Harga Beras & $-0,022$ & $-0,007$ \\
\hline Harga Jagung & $(-)$ & $(-)$ \\
\hline Harga Ubi Kayu & $-0,0001$ & $-0,0004$ \\
\hline Harga Ikan & 0,001 & 0,013 \\
\hline Harga Daging Ayam & 0,0002 & $-0,010$ \\
\hline Harga Telur & $-0,001$ & 0,011 \\
\hline Elastisitas Pendapatan & 0,006 & 0,044 \\
\hline
\end{tabular}

Sumber : Analisis Data Susenas, 2002.

Keterangan : * Signifikan pada taraf kesalahan 5\%

( - ) Rumah tangga tidak mengkonsumsi pangan tersebut

Secara umum untuk rumah tangga pedesaan maupun perkotaan pada berbagai tingkat pendapatan, nilai elastisitas harga daging sapi mempunyai nilai negatif, hal ini sesuai dengan hukum permintaan, yang menyatakan bahwa "bila harga suatu barang naik maka ceteris paribus jumlah yang diminta konsumen akan barang tersebut turun dan sebaliknya bila harga barang tersebut turun". Nilai elastisitas harga daging sapi yang lebih kecil dari satu artinya pemintaan daging sapi untuk konsumsi rumah tangga bersifat inelastis artinya persentase perubahan daging sapi yang diminta lebih kecil dari persentase perubahan harga daging sapi. 
Nilai elastisitas harga barang lain terhadap konsumsi daging sapi untuk rumahtangga di pedesaan maupun perkotaan pada tingkat pendapatan menengah dan tinggi, pada umumnya daging sapi mempunyai komplementer dengan ubi kayu, telur dan beras karena pada umumnya rumah tangga mengkonsumsi daging sapi, telur, ubi kayu dan beras secara bersama-sama. Pada tingkat pendapatan tinggi di pedesaanndan perkotaan, daging sapi mempunyai hubungan substitusi dengan telur, namun tidak. signifikan secara statistik.

Nilai elastisitas pendapatan di perkotaan pada tingkat pendapatan menengah dan tinggi serta pendapatan tinggi di pedesaan menunjukkan elastisitas pendapatan tidak signifikan secara statistik. Elastisitas pendapatan di pedesaan pada tingkat pendapatan menengah menunjukkan bahwa daging sapi merupakan barang kebutuhan pokok, ini berarti apabila pendapatan meningkat maka konsumsi daging sapi bertambah atau sebaliknya namun proporsi peningkatan atau penurunan konsumsi daging sapi lebih kecil dari proporsi kenaikan ataupun penurunan pendapatan.

\section{Elastisitas Konsumsi Daging Ayam}

Hasil analisis elastisitas harga sendiri, elastisitas harga silang dan elastisitas pendapatan konsumsi daging ayam rumah tangga di pedesaan pada berbagai tingkat pendapatan dan perkotaan pada tingkat pendapatan menengah dan tinggi selengkapnya dapat dilihat pada tabel 11 dan 12 .

Tabel 11. Elastisitas Harga Sendiri, Harga Silang dan Pendapatan Terhadap Konsumsi Daging Ayam Rumah Tangga Pada Daerah Pedesaan Menurut Tingkat Pendapatan di Propinsi Lampung

\begin{tabular}{lrrr}
\hline \multirow{2}{*}{ Elastisitas } & \multicolumn{3}{c}{ Tingkat Pendapatan } \\
\cline { 2 - 4 } & \multicolumn{1}{c}{ Rendah } & Menengah & \multicolumn{1}{c}{ Tinggi } \\
\hline Elastisitas Harga Daging Ayam & $-1,255^{*}$ & $-0,395^{*}$ & $-0,847^{*}$ \\
Elastisitas Harga Silang : & & & \\
Harga Beras & $-1,162^{*}$ & $-0,096$ & $-0,128$ \\
Harga Jagung & $-0,556^{*}$ & $(-)$ & $(-)$ \\
Harga Ubi Kayu & $0,005^{*}$ & 0,00016 & 0,0002 \\
Harga Ikan & 0,003 & 0,001 & 0,004 \\
Harga Daging Sapi & $(-)$ & 0,020 & 0,060 \\
Harga Telur & $0,022^{*}$ & 0,001 & 0,001 \\
Elastisitas Pendapatan & $2,726^{*}$ & 0,028 & 0,093 \\
\hline
\end{tabular}

Sumber : Analisis Data Susenas, 2002.

Keterangan : * Signifikan pada taraf kesalahan 5\%

( - ) Rumah tangga tidak mengkonsumsi pangan tersebut 
Tabel 12. Elastisitas Harga Sendiri, Harga Silang dan Pendapatan Terhadap Konsumsi Daging Ayam Rumah Tangga Pada Daerah Perkotaan Menurut Tingkat Pendapatan di Propinsi Lampung

\begin{tabular}{lrr} 
Elastisitas & \multicolumn{2}{c}{ Tingkat Pendapatan } \\
\cline { 2 - 3 } & \multicolumn{1}{c}{ Menengah } & \multicolumn{1}{c}{ Tinggi } \\
\hline Elastisitas Harga Daging Ayam & $-1,211^{*}$ & $-1,621^{*}$ \\
Elastisitas Harga Silang : & $-0,352$ & $-0,001$ \\
Harga Beras & $(-)$ & $(-)$ \\
Harga Jagung & $-0,0005$ & $-0,0005$ \\
Harga Ubi Kayu & 0,0001 & 0,005 \\
Harga Ikan & 0,023 & $-0,015$ \\
Harga Daging Sapi & $-0,005$ & 0,012 \\
Harga Telur & 0,335 & 0,053 \\
Elastisitas Pendapatan & &
\end{tabular}

Sumber : Analisis Data Susenas, 2002.

Keterangan : * Signifikan pada taraf kesalahan 5\%

( - ) Rumah tangga tidak mengkonsumsi pangan tersebut

Secara umum untuk rumah tangga pedesaan maupun perkotaan pada berbagai tingkat pendapatan, nilai elastisitas harga daging sapi mempunyai nilai negatif, hal ini sesuai dengan hukum permintaan, yang menyatakan bahwa "bila harga suatu barang naik maka ceteris paribus jumlah yang diminta konsumen akan barang tersebut turun dan sebaliknya bila harga barang tersebut turun". Nilai elastisitas harga daging ayam pada tingkat pendapatan menengah dan tinggi di pedesaan menunjukkan nilai elastisitas yang lebih kecil dari satu, artinya permintaan daging ayam untuk konsumsi rumah tangga bersifat inelastis artinya persentase perubahan daging ayam yang diminta lebih kecil dari persentase perubahan harga daging ayam. Sedangkan nilai elastisitas harga daging ayam pada tingkat pendapatan menengah dan tinggi di perkotaan serta tingkat pendapatan rendah di pedesaan menunjukkan nilai elastisitas yang lebih besar satu, artinya pemintaan daging ayam untuk konsumsi rumah tangga bersifat elastis artinya pesentase perubahan daging ayam yang diminta lebih besar dari persentase perubahan harga daging ayam.

Nilai elastisitas harga barang lain terhadap konsumsi daging ayam untuk rumah tangga di pedesaan pada tingkat pendapatan rendah, pada umumnya daging ayam mempunyai hubungan komplementer dengan jagung dan beras karen pada umumnya rumah tangga mengkonsumsi daging ayam sebagai pelengkap beras dan jagung. Namun mempunyai hubungan substitusi dengan ubi kayu dan telur, artinya jika konsumsi daging ayam meningkat maka rumah tangga tidak akan mengkonsumsi telur dan ubi kayu. Pada tingkat pendapatan tinggi di pedesaan, daging ayam mempunyai hubungan substitusi dengan daging sapi, artinya jika rumah tangga tidak mengkonsumsi daging ayam maka digantikan dengan mengkonsumsi daging sapi dan sebaliknya. Demikian halnya dengan pendapatan menengah di perkotaan, daging ayam mempunyai substitusi dengan daging sapi tetapi tidak signifikan secara statistik.

Elastisitas pendapatan di pedesaan pada tingkat pendapatan rendah menunjukkan bahwa daging ayam merupakan barang mewah, ini berarti apabila 
pendapatan meningkat maka konsumsi daging ayam bertambah atau sebaliknya dengan proporsi peningkatan ataupun penurunan konsumsi daging ayam yang lebih besar dari proporsi kenaikan ataupun penurunan pendapatan.

\section{Elastisitas Konsumsi Telur}

Hasil analisis elastisitas harga sendiri, elastisitas harga silang dan elastisitas, pendapatan konsumsi telur rumah tangga di pedesaan dan perkotaan pada berbagai tingkat pendapatan dapat dilihat pada tabel 13 dan 14 .

Tabel 13. Elastisitas Harga Sendiri, Harga Silang dan Pendapatan Terhadap Konsumsi Telur Rumah Tangga Pada Daerah Pedesaan Menurut tingkat Pendapatan di Propinsi Lampung

\begin{tabular}{lrrr}
\hline \multirow{2}{*}{ Elastisitas } & \multicolumn{3}{c}{ Tingkat Pendapatan } \\
\cline { 2 - 4 } & \multicolumn{1}{c}{ Rendah } & Menengah & \multicolumn{1}{c}{ Tinggi } \\
\hline Elastisitas Harga Daging Ayam & $-0,396^{*}$ & $-0,507^{*}$ & $-0,471^{*}$ \\
Elastisitas Harga Silang : & & & \\
Harga Beras & $-0,014$ & $0,321^{*}$ & $-0,103$ \\
Harga Jagung & $-0,005$ & $(-)$ & $(-)$ \\
Harga Ubi Kayu & 0,0001 & $-0,00006$ & $0,0007^{*}$ \\
Harga Ikan & 0,005 & 0,0002 & $-0,011^{*}$ \\
Harga Daging Sapi & $(-)$ & 0,010 & 0,029 \\
Harga Telur & 0,014 & $0,014^{*}$ & $0,013^{*}$ \\
Elastisitas Pendapatan & 0,112 & $-0,437^{*}$ & 0,020 \\
\hline
\end{tabular}

Sumber: Analisis Data Susenas, 2002.

Keterangan : * Signifikan pada taraf kesalahan 5\%

( - ) Rumah tangga tidak mengkonsumsi pangan tersebut

Tabel 14. Elastisitas Harga Sendiri, Harga Silang dan Pendapatan Terhadap Konsumsi Telur Rumah Tangga Pada Perkotaan Menurut Tingkat Pendapatan di Propinsi Lampung

\begin{tabular}{lrrr}
\hline \multirow{2}{*}{ Elastisitas } & \multicolumn{3}{c}{ Tingkat Pendapatan } \\
\cline { 2 - 4 } & \multicolumn{1}{c}{ Rendah } & Menengah & \multicolumn{1}{c}{ Tinggi } \\
\hline Elastisitas Harga Daging Ayam & $-1,312^{*}$ & $-1,667^{*}$ & $-2,224^{*}$ \\
Elastisitas Harga Silang : & & & \\
Harga Beras & $-2,685$ & $-0,194$ & $-0,0005$ \\
Harga Jagung & $(-)$ & $(-)$ & $(-)$ \\
Harga Ubi Kayu & $-0,0013$ & $-0,0025^{*}$ & $-0,0025^{*}$ \\
Harga Ikan & 0,015 & $-0,0146$ & 0,016 \\
Harga Daging Sapi & $(-)$ & $0,021^{*}$ & 0,02 \\
Harga Telur & $(-)$ & 0,001 & $-0,016$ \\
Elastisitas Pendapatan & $2,517^{*}$ & 0,284 & 0,107 \\
\hline Sumber
\end{tabular}

Sumber: Analisis Data Susenas, 2002.

Keterangan : * Signifikan pada taraf kesalahan 5\%

( - ) Rumah tangga tidak mengkonsumsi pangan tersebut 
Secara umum untuk rumah tangga pedesaan maupun perkotaan pada berbagai tingkat pendapatan, nilai elastisitas harga telur mempunyai negatif, hal ini sesuai dengan hukum permintaan, yang menyatakan bahwa "bila harga suatu barang naik maka ceteris patibus jumlah yang diminta konsumen akan barang tersebut turun dan sebaliknya bila harga barang tersebut turun". Nilai elastisitas harga telur pada tingkat pendapatan rendah, menengah dan tinggi di pedesaan menunjukkan nilai elastisitas yang lebih kecil dari satu, artinya pemintaan telur unutk konsumsi rumah tangga bersifat inelastis artinya persentase perubahan telur yang diminta lebih kecil dari persentase perubahan harga telur. Sedangkan nilai elastisitas harga telur pada tingkat pendapatan rendah, menengah dan tinggi di perkotaan menunjukkan nilai elastisitas yang lebih besar dari satu, artinya pemintaan telur untuk konsumsi rumah tangga bersifat elastis artinya persentase perubahan telur yang diminta lebih besar dari persentase perubahan harga telur.

Nilai elastisitas harga barang lain terhadap konsumsi telur untuk rumah tangga di pedesaan pada tingkat pendapatan rendah, telur mempunyai hubungan komplementer dengan beras dan jagung karena pada umumnya rumah tangga mengkonsumsi telur sebagai pelengkap beras dan jagung, namun mempunyai hubungan substitusi dengan ikan, artinya jika konsumsi telur meningkat maka rumah tangga tidak akan mengkonsumsi ikan. Pada tingkat pendapatan menengah, telur mempunyai hubungan substitusi dengan beras dan daging ayam. Pada tingkat pendapatan tinggi di pedesaan, telur mempunyai hubungan substitusi dengan ubikayu dan daging ayam, artinya jika rumah tangga tidak mengkonsumsi telur maka digantikan dengan mengkonsumsi daging ayam dan sebaliknya.

Nilai elastisitas harga barang lain terhadap konsumsi telur untuk rumah tangga diperkotaan pada tingkat pendapatan rendah, telur mempunyai hubungan komplementer dengan beras karena pada umumnya rumah tangga mengkonsumsi telur sebagai pelengkap beras. Pada tingkat pendapatan menengah, telur mempunyai hubungan komplementer dengan ubi kayu karena pada umumnya rumah tangga mengkonsumsi telur sebagai pelengkap ubikayu, tetapi telur mempunyai hubungan substitusi dengan daging sapi artinya jika tidak mengkonsumsi telur maka digantikan dengan mengkonsumsi daging sapi. Pada tingkat pendapatan tinggi, telur mempunyai hubungan komplementer dengan ubikayu, artinya telur dan ubi kayu dikonsumsi secara bersamasama.

Nilai elastisitas pendapatan di pedesaan pada tingkat pendapatan rendah dan tinggi, serta di perkotaan pada tingkat pendapatan menengah dan tinggi menunjukkan elastisitas pendapatan tidak signifikan secara statistik. Nilai elastisitas pendapatan di pedesaan pada tingkat pendapatan menengah menunjukkan bahwa telur merupakan barang inferior, ini berarti apabila pendapatan meningkat maka konsumsi telur berkurang atau sebaliknya telur yang dikonsumsi akan meningkat dengan berkurangnya pendapatan. Sedangkan elastisitas pendapatan di perkotaan pada tingkat pendapatan rendah menunjukkan bahwa telur merupakan barang mewah, ini berarti apabila pendapatan meningkat maka konsumsi telur bertambah atau sebaliknya dengan proporsi peningkatan ataupun penurunan konsumsi telur yang lebih besar dari proporsi kenaikan ataupun penurunan pendapatan. 


\section{Elastisitas Harga Sendiri Konsumsi Pangan Rumah Tangga}

Tabel 15 menunjukkan bahwa ikan merupakan jenis pangan yang permintaannya bersifat elastis pada berbagai tingkat pendapatan di daerah pedesaan dan perkotaan, sedangkan beras merupakan jenis pangan yang permintaannya bersifat inelastis pada berbagai tingkat pendapatan di daerah pedesaan dan perkotaan. Jangung hanya dikonsumsi oleh rumah tangga pada tingkat pendapatan rendah di daerah pedesaan permintaan jagung untuk konsumsi bersifat inelastis bari rumah tangga pada tingkat pendapatan rendah di daerah pedesaan.

Tabel 15. Jenis Konsumsi Pangan Rumah Tangga pada Berbagai Tingkat Pendapatan di Perkotaan dan Pedesaan Menurut Elastisitas Harga Sendiri di Propinsi Lampung

\begin{tabular}{cllllll}
\hline \multirow{2}{*}{ Jenis } & \multicolumn{3}{c}{ Perkotaan } & & Pedesaan \\
\cline { 2 - 7 } Barang & $\begin{array}{c}\text { Pendapatan } \\
\text { Rendah }\end{array}$ & $\begin{array}{c}\text { Pendapatan } \\
\text { Menengah }\end{array}$ & $\begin{array}{c}\text { Pendapatan } \\
\text { Tinggi }\end{array}$ & $\begin{array}{c}\text { Pendapatan } \\
\text { Rendah }\end{array}$ & $\begin{array}{c}\text { Pendapatan } \\
\text { Menengah }\end{array}$ & $\begin{array}{c}\text { Pendapatan } \\
\text { Tinggi }\end{array}$ \\
\hline Elastisitas & $\begin{array}{l}\text { Ubi Kayu } \\
\text { Ikan }\end{array}$ & $\begin{array}{ll}\text { Ikan } \\
\text { Daging }\end{array}$ & $\begin{array}{l}\text { Ikan } \\
\text { Daging }\end{array}$ & $\begin{array}{l}\text { Ikan } \\
\text { Daging }\end{array}$ & Ikan & Ikan \\
& & Ayam & Ayam & Ayam & & \\
& Telur & Telur & Telur & & & \\
Inelatis & Beras & Beras & Beras & Beras & Beras & Beras \\
& & Ubi Kayu & Ubi Kayu & Jagung & Ubi Kayu & Ubi Kayu \\
& & Daging & Daging & Ubi Kayu & Daging & Daging \\
& & Sapi & Sapi & & Sapi & Sapi \\
& & & & Telur & Daging & Daging \\
& & & & & Ayam & Ayam \\
& & & & & Telur & Telur \\
\hline
\end{tabular}

Sumber : Analisis Data Susenas, 2002

Permintaan ubi kayu untuk konsumsi rumah tangga pada tingkat pendapatan rendah di daerah perkotaan bersifat elastis, sedangkan pada tingkat pendapatan menengah, tinggi dan berbagai tingkat pendapatan di daerah pedesaan, permintaan ubi kayu bersifat inlestis. Permintaan daging sapi untuk konsumsi rumah tangga di daerah pedesaan dan perkotaan pada tingkat pendapatan menengah dan tinggi bersifat inelastis.

Permintaan daging ayam untuk konsumsi rumah tangga di daerah pedesaan pada tingkat pendapatan menengah dan tinggi bersifat inelastis; sedangkan pada tingkat pendapatan rendah di daerah pedesaan, pendapatan menengah dan tinggi di daerah perkotaan bersifat elastis. Permintaan telur untuk konsumsi rumah tangga di daerah pedesaan pada berbagai tingkat pendapatan bersifat inelastis, sedangkan di daerah perkotaan tingkat pendapatan bersifat elastis.

\section{Elastisitas Harga Silang Konsumsi Pangan Rumah Tangga}

Tabel 16 menunjukkan bahwa rumah tangga di daerah pedesaan pada tingkat rendah, beras mempunyai hubungan komplementer dengan ikan, sedangkan pada pendapatan menengah beras komplementer dengan ikan telur. Rumah tangga di daerah perkotaan pada tingkat pendapatan menengah, beras mempunyai subtitusi dengan ubi kayu dan komplementernya dengan ikan. Rumah tangga di daerah pedesaan pada tingkat 
pendapatan rendah dan menengah ubi kayu mempunyai hubungan komplementer dengan ikan. Rumah tangga di daerah perkotaan pada tingkat rendah, ubi kayu mempunyai hubungan substitusi dengan beras dan komplementernya dengan ikan dan telur, sedangkan pada tingkat pendapatan menengah, ubi kayu mempunyai hubungan komplementer dengan telur.

Tabel 16. Jenis Konsumsi Pangan Rumah Tangga pada Berbagai Tingkat Pendapatan di Pedesaan Menurut Elastisitas Harga Silang di Propinsi Lampung

\begin{tabular}{|c|c|c|c|c|c|c|}
\hline \multirow{2}{*}{$\begin{array}{l}\text { Jenis } \\
\text { Pangan }\end{array}$} & \multicolumn{2}{|c|}{ Pendapatan Rendah } & \multicolumn{2}{|c|}{ Pendapatan Menengah } & \multicolumn{2}{|c|}{ Pendapatan Tinggi } \\
\hline & $\begin{array}{c}\text { Barang } \\
\text { Substitusi } \\
\end{array}$ & $\begin{array}{c}\text { Barang } \\
\text { Komplementer }\end{array}$ & $\begin{array}{c}\text { Barang } \\
\text { Substitusi } \\
\end{array}$ & $\begin{array}{c}\text { Barang } \\
\text { Komplementer }\end{array}$ & $\begin{array}{c}\text { Barang } \\
\text { Substitusi }\end{array}$ & $\begin{array}{c}\text { Barang } \\
\text { Komplementer } \\
\end{array}$ \\
\hline Beras & - & Ikan & & $\begin{array}{l}\text { Ikan } \\
\text { Telur }\end{array}$ & - & - \\
\hline Jagung & - & - & - & - & - & - \\
\hline $\begin{array}{l}\text { Ubi } \\
\text { Kayu }\end{array}$ & - & Ikan & & Ikan & - & Ikan \\
\hline Ikan & - & - & - & Ubi Kayu & $\begin{array}{l}\text { Daging } \\
\text { Sapi } \\
\text { Telur }\end{array}$ & - \\
\hline $\begin{array}{l}\text { Daging } \\
\text { Sapi }\end{array}$ & - & - & - & Ubi Kayu & - & - \\
\hline $\begin{array}{l}\text { Daging } \\
\text { Ayam }\end{array}$ & $\begin{array}{l}\text { Ubi Kayu } \\
\text { Telur }\end{array}$ & $\begin{array}{l}\text { Beras } \\
\text { Jagung }\end{array}$ & - & $\begin{array}{l}\text { Telur } \\
-\end{array}$ & - & - \\
\hline Telur & Ikan & - & $\begin{array}{l}\text { Beras } \\
\text { Daging } \\
\text { Ayam } \\
\end{array}$ & - & $\begin{array}{l}\text { Ubi Kayu } \\
\text { Daging } \\
\text { Ayam }\end{array}$ & Ikan \\
\hline
\end{tabular}

Di daerah pedesaan pada rumah tangga tingkat pendapatan menengah, ikan komplmenternya dengan ubi kayu; sedangkan pada tingkat pendapatan tinggi, konsumsi ikan disubstitusi oleh daging sapi dan telur. Di daerah perkotaan pada tingkat pendapatan rendah, ikan mempunyai hubungan komplementer dengan ubi kayu; sedangkan pada tingkat pendapatan tinggi, konsumsi ikan berkomplementer dengan ubi kayu dan daging.

Pada tingkat pendapatan menengah di daerah pedesaan, konsumsi daging sapi komplementer dengan ubi kayu dan telur. Pada tingkat pendapatan menengah di daerah perkotaan, konsumsi daging sapi komplementer dengan beras. Pada rumah tangga tingkat pendapatan rendah di daerah pedesaan, konsumsi daging ayam dapat disubstitusi oleh telur dan ubi kayu sedangkan komplementernya adalah beras dan jagung.

Di daerah pedesaan pada tingkat pendapatan rendah, konsumsi telur dapat disubstitusi oleh ikan; pada tingkat pendapatan menengah, konsumsi telur dapat disubstitusi oleh daging ayam dan beras; sedangkan pada tingkat pendapatan tinggi, konsumsi telur komplementer dengan ikan dapat disubstitusi oleh daging ayam dan ubi kayu. Di daerah perkotaan pada tingkat pendapatan menengah, konsumsi telur dapat disubstitusi oleh daging sapi dan komplementernya adalah ubi kayu; sedangkan pada tingkat pendapatan tinggi, konsumsi telur komplementer dengan ubi kayu. 
Tabel 17. Jenis Konsumsi Pangan Rumah Tangga pada Berbagai Tingkat Pendapatan di Perkotaan Menurut Elastisitas Harga Silang di Propinsi Lampung

\begin{tabular}{|c|c|c|c|c|c|c|}
\hline \multirow[b]{2}{*}{$\begin{array}{c}\text { Jenis } \\
\text { Pangan }\end{array}$} & \multicolumn{2}{|c|}{ Pendapatan Rendah } & \multicolumn{2}{|c|}{ Pendapatan Menengah } & \multicolumn{2}{|c|}{ Pendapatan Tinggi } \\
\hline & $\begin{array}{c}\text { Barang } \\
\text { Substitusi }\end{array}$ & $\begin{array}{c}\text { Barang } \\
\text { Komplementer }\end{array}$ & $\begin{array}{c}\text { Barang } \\
\text { Substitusi }\end{array}$ & $\begin{array}{c}\text { Barang } \\
\text { Komplementer }\end{array}$ & $\begin{array}{c}\text { Barang } \\
\text { Substitusi }\end{array}$ & $\begin{array}{c}\text { Barang } \\
\text { Komplementer }\end{array}$ \\
\hline Beras & - & 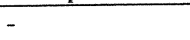 & Ubi Kayu & Ikan & - & - \\
\hline Ubi Kayu & - & $\begin{array}{l}\text { Ikan } \\
\text { Telur }\end{array}$ & - & Telur & - & - \\
\hline Ikan & - & Ubi kayu & - & - & - & $\begin{array}{l}\text { Ubi Kayu } \\
\text { Daging Sapi }\end{array}$ \\
\hline $\begin{array}{l}\text { Daging } \\
\text { Sapi }\end{array}$ & - & - & - & Beras & - & - \\
\hline $\begin{array}{l}\text { Daging } \\
\text { Ayam }\end{array}$ & - & - & - & - & - & - \\
\hline Telur & - & - & $\begin{array}{l}\text { Daging } \\
\text { Sapi }\end{array}$ & Ubi Kayu & & Ubi Kayu \\
\hline
\end{tabular}

Sumber : Analisis Data Susenas, 2002.

\section{Elastisitas Pendapatan Konsumsi Pangan Rumah Tangga}

Tabel 18 menunjukkan bahwa Rumah tangga di daerah pedesaan dan perkotaan pada berbagai tingkat pendapatan menganggap beras sebagai barang kebutuhan pokok. Rumah tangga di daerah pedesaan pada tingkat pendapatan menengah, tinggi dan berbagai tingkat pendapatan di daerah perkotaan, ubi kayu tergolong barang inferior. Sedangkan pada rumah tangga tingkat pendapatan rendah di daerah pedesaan, ubi kayu tergolong barang kebutuhan pokok.

Tabel 18. Jenis Konsumsi Pangan Rumah Tangga pada Berbagai Tingkat Pendapatan di Perkotaan dan Pedesaan Menurut Elastisitas Pendapatan di Propinsi Lampung

\begin{tabular}{|c|c|c|c|c|c|c|}
\hline \multirow[b]{2}{*}{$\begin{array}{c}\text { Jenis } \\
\text { Barang }\end{array}$} & \multicolumn{3}{|c|}{ Perkotaan } & \multicolumn{3}{|c|}{ Pedesaan } \\
\hline & $\begin{array}{c}\text { Pendapatan } \\
\text { Rendah }\end{array}$ & $\begin{array}{c}\text { Pendapatan } \\
\text { Menengah }\end{array}$ & $\begin{array}{c}\text { Pendapatan } \\
\text { Tinggi }\end{array}$ & $\begin{array}{c}\text { Pendapatan } \\
\text { Rendah }\end{array}$ & $\begin{array}{c}\text { Pendapatan } \\
\text { Menengah }\end{array}$ & $\begin{array}{c}\text { Pendapatan } \\
\text { Tinggi } \\
\end{array}$ \\
\hline Mewah & Ikan & - & - & $\begin{array}{l}\text { Daging } \\
\text { Ayam }\end{array}$ & - & - \\
\hline Pokok & $\begin{array}{l}\text { Telur } \\
\text { Beras }\end{array}$ & $\begin{array}{l}\text { Beras } \\
\text { Ikan } \\
\text { Daging Sapi } \\
\text { Daging } \\
\text { Ayam } \\
\text { Telur }\end{array}$ & $\begin{array}{l}\text { Beras } \\
\text { Ikan } \\
\text { Daging Sapi } \\
\text { Daging } \\
\text { Ayam } \\
\text { Telur }\end{array}$ & $\begin{array}{l}\text { Beras } \\
\text { Ubi Kayu } \\
\text { Ikan } \\
\text { Telur }\end{array}$ & $\begin{array}{l}\text { Beras } \\
\text { lkan } \\
\text { Daging Sapi } \\
\text { Dading } \\
\text { Ayam }\end{array}$ & $\begin{array}{l}\text { Beras } \\
\text { Ikan } \\
\text { Daging Sapi } \\
\text { Daging } \\
\text { Ayam } \\
\text { Telur }\end{array}$ \\
\hline Inferior & Ubi Kayu & Ubi Kayu & Ubi Kayu & Jagung & $\begin{array}{l}\text { Ubi Kayu } \\
\text { Telur }\end{array}$ & Ubi Kayu \\
\hline
\end{tabular}

Sumber : Analisis Data Susenas, 2002.

Rumah tangga di daerah pedesaan pada berbagai tingkat pendapatan dan di daerah perkotaan pada tingkat pendapatan menengah dan tinggi, ikan tergolong barang kebutuhan pokok. Sedangkan rumah tangga di daerah perkotaan pada tingkat pendapatan rendah tergolong barang mewah. Rumah tangga di daerah pedesaan dan perkotaan pada tingkat pendapatan menengah dan tinggi, daging sapi tergolong barang kebutuhan pokok 
Daging ayam bagi rumah tangga di daerah pedesaan pada tingkat pendapatan rendah tergolong barang mewah. Sedangkan bagi rumah tangga di daerah pedesaan dan perkotaan pada tingkat pendapatan menengah dan tinggi, daging ayam tergolong barang kebutuhan pokok. Pada rumah tangga tingkat pendapatan menengah di pedesaan, telur tergolong barang inferior. Sedangkan pada tingkat pendapatan rendah di daerah perkotaan, telur tergolong barang mewah.

\section{KESIMPULAN DAN SARAN}

Hasil penelitian menunjukkan bahwa: (1) Permintaan beras dan daging sapi untuk konsumsi rumah tangga pada berbagai tingkat pendapatan di pedesaan dan perkotaan bersifat inelastis. Jagung hanya dikonsumsi oleh rumah tangga pada tingkat pendapatan rendah di daerah pedesaan dan permintaannya bersifat inelastis; (2) Permintaan ubi kayu untuk konsumsi rumah tangga pada tingkat pendapatan rendah di daerah perkotaan bersifat elastis, sedangkan pada tingkat pendapatan menengah, tinggi dan berbagai tingkat pendapatan di daerah pedesaan, permintaan ubi kayu bersifat inelastis. Permintaan ikan untuk konsumsi rumah pada berbagai tingkat pendapatan di pedesaan dan perkotaan bersifat elastis. Permintaan daging ayam untuk konsumsi rumah tangga di daerah pedesaan pada tingkat pendapatan menengah dan tinggi bersifat inelastis. Sedangkan pada tingkat pendapatan rendah di daerah pedesaan, pendapatan menengah dan tinggi di daerah perkotaan bersifat elastis. Permintaan telur untuk konsumsi rumah tangga di daerah pedesaan pada berbagai tingkat pendapatan bersifat inelastis, sedangkan di daerah perkotaan pada berbagai tingkat pendapatan bersifat elastis; (4) Rumah tangga di daerah pedesaan dan perkotaan pada berbagai tingkat pendapatan, beras mempunyai hubungan komplementer dengan ikan dan mempunyai hubungan substitusi dengan ubi kayu. Ubi kayu mempunyai hubungan komplementer dengan beras dan ikan namun bersubstitusi dengan daging ayam. Pada rumah di pedesaan dan perkotaan, ikan berkomplementer dengan ubi kayu dan disubstitusi oleh daging sapi, daging ayam dan telur. Pada tingkat pendapatan menengah di daerah pedesaan dan perkotaan, konsumsi daging sapi komplementer dengan beras, ubi kayu dan telur. Pada rumah tangga tingkat pendapatan rendah di daerah pedesaan, konsumsi daging ayam dapat disubstitusi oleh telur dan ubi kayu, sedangkan komplementernya adalah beras dan jagung. Di daerah pedesaan dan perkotaan pada berbagai tingkat pendapatan, telur dapat disubstitusi oleh ikan dan komplementernya adalah beras dan ubi kayu; (5) Rumah tangga di daerah pedesaan dan perkotaan pada berbagai tingkat pendapatan menganggap beras sebagai barang kebutuhan pokok. Rumah tangga di daerah pedesaan dan perkotaan pada tingkat pendapatan menengah dan tinggi, daging sapi tergolong barang kebutuhan pokok. Pada rumah tangga tingkat menengah di pedesaan, terlur tergolong barang inferior. Sedangkan pada tingkat pendapatan rendah di daerah perkotaan, telur tergolong mewah.

Berdasarkan hasil penelitian diatas, disarankan bagi masyarakat untuk menganekaragamkan konsumsi pangan. Selain itu disarankan bagi Pemerintah Propinsi Lampung untuk memberikan subsidi pangan pada masyarakat rendah khususnya kebutuhan pokok 


\section{DAFTAR PUSTAKA}

Badan Pusat Statistik, 1996. Pengeluaran Konsumsi Penduduk Propinsi Lampung 1996. Badan Pusat Statistik Propinsi Lampung. , 1999. Pengeluaran Konsumsi Penduduk Propinsi Lampung 1999. Badan Pusat Statistik Propinsi Lampung. , 2002. Pengeluaran Konsumsi Pendududk Propinsi Lampung 2002. Badan' Pusat Statistik Propinsi Lampung. , 2002. Pengeluaran Untuk Konsumsi Penduduk Indonesia per Propinsi, Badan Pusat Statistik. Jakarta.

Berg, A., 1986. Peranan Gizi dalam Pembangunan Nasional. PT. Rajawali, Jakarta.

De Rossi, B.B., 2000. Faktor Pembeda Keragaman Konsumsi Bahan Pangan Pokok di Propinsi Nusa Tenggara Timur. Tesis Program Pascasarjana Universitas Gadjah Mada, Yogyakarta.

Endang, Yektiningsih, 1998. Analisis Permintaan Buah Lokal dan Impor di Kotamadya Surabaya. Tesis Program Pascasarjana Universitas Gadjah Mada, Yogyakarta.

Greene William H., 1993. Econometric Analysis. Second Edition Macmillan Publishing Company, New York.

Mulatsih, N.T., 2003. Analisis Distribusi Pengeluaran Konsumsi Per Kapita Di Indonesia dan Faktor-Faktor Yang Mempengaruhinya 1987-1999. Tesis Program Pascasarjana Universitas Gadjah Mada, Yogyakarta.

Onianti, C., 2002. Analisis Konsumsi Buah-buahan pada tingkat Rumah Tangga Di Daerah Istimewa Yogyakarta. Tesis Program Pasacasarjana Universitas Gadjah Mada, Yogyakarta.

Wijayanti, I.K.E., 1999. Analisis Konsumsi Pangan Hewani Pada Tingkat Rumah Tangga di Daerah Istimewa Yogyakarta. Tesis Program Pascasarjana Universitas Gadjah Mada, Yogyakarta. 